\title{
Retinal response in the post metamorphic American eel (Anguilla rostrata) (Pisces, Teleostei)
}

\author{
* Mohamed Ather $\mathrm{Ali}^{1}$, Jean-Denis Dutil ${ }^{2}$ \& Lyne Fortier ${ }^{1}$ \\ ${ }^{1}$ Département de Biologie; Université de Montréal; Canada \\ ${ }^{2}$ Ministère des Pêches et des Océans, Gouvernement du Canada; \\ 850 route de la mer, Mont-Joli, Québec, G5H 324, Canada
}

\begin{abstract}
Retinas of light and dark adapted post metamorphic American eel Anguilla rostrata were examined. The retinal epithelial pigment migrates vitreally in light and sclerally in darkness. Two layers of rods and a layer of single cones are present. Some cones elongate slightly in the dark and contract in the light. The cone synaptic ribbons show no difference between the light and dark adapted stages. It appears that this eel stage is capable of functioning in bright and dim environments.
\end{abstract}

\section{INTRODUCTION}

The retina of the catadromous eel, both the European (Anguilla anguilla) and the North American (Anguilla rostrata, Lesueur) species, had been studied from the point of view of morphology (Ali et al., 1968; Braekevelt, 1982, 1984a, $b, 1985$; Gordon et al., 1978), histophysiology (Blaxter \& Staines, 1970; Es-sounni \& Ali, 1986, 1987; Pankhurst, 1984) and visual pigments (Beatty, 1975). The eel migrates twice during its life and undergoes two metamorphoses (Tesch, 1977) which bring about numerous morphological and physiological modifications (Kleckner \& Krueger, 1981; Pankhurst \& Sørensen, $1984)$. Studies on the retina have dealt with various stages. Blaxter \& Staines (1970) found only rods in the European leptocephalus larva and no retinomotor responses (cf. Ali, 1971). In the yellow and silver stages of the European species, Es-sounni \& Ali (1986, 1987) did not observe any movement of the photoreceptors although the retinal epithelial pigment (REP) did migrate vitreally in response to light (see also Vilter, 1946, 1951), while Gordon et al. (1978) in a physiological study on the yellow eel stage of $A$. rostrata found two cone mediated responses. This paper presents the results of histophysiological study of retinal responses in the post metamorphic larval stage of $A$. rostrata.

\section{MATERIAL AND METHODS}

Specimens of juvenile Anguilla rostrata at stage VI $A_{0}$ to VI $A_{3}$ (Elie et al., 1982), characterized by the beginning of dorsal pigmentation, were captured in the estuary of Musquash river, New Brunswick, in May 1984.

- Correspondence to be sent to Prof. M. A. Ali, Département de biologie, Université de Montréal, C. P. 6128, Succ. "A", Montréal, Québec, Canada H3C 3J7. 
Specimens were maintained under natural photic conditions and decapitated after $2 \mathrm{~h}$ in light and $2 \mathrm{~h}$ in darkness. The heads were then put in the fixative $1 \%$ paraformaldehyde, $1 \%$ glutaraldehyde buffered at $\mathrm{pH} \cdot 7.2)$. They were rinsed in buffered sucrose $(7 \%)$, postfixed in $1 \%$ osmium tetroxide buffered with phosphate for an hour at $4{ }^{\circ} \mathrm{C}$ and then dehydrated through a graded series of ethanol $(40 \%$ to $100 \%)$ and embedded in Spurr's epoxy resin via propylene oxide. Polymerisation was carried out at $60^{\circ} \mathrm{C}$ for $72 \mathrm{~h}$. Sections were cut with glass knives with an LKB ultramicrotome. Semi-thin sections $(1 \mu \mathrm{m})$ were placed on glass slides, stained with toluidine blue and examined with a Zeiss light microscope. Thin sections were collected on copper grids $\mathrm{H} 200$, stained with uranyl acetate and lead citrate, and examined with a JEOL electron microscope (JEM 100S) at an operating voltage of $80 \mathrm{kV}$.

\section{RESULTS AND DISCUSSION}

The retina of this eel stage consists of all the classical layers of the vertebrate duplex retina (Figs 1,2). The rods are organized in two layers and show no movement in response to light and darkness. The cones are organized in one layer. While it is clear that the retinal pigment of this eel stage is capable of migration into apical process vitreally in light (Fig. 1) and sclerally in darkness (Fig. 2), the situation in the case of the cones is more complex. Some of the cones appear capable of slight elongation in the dark (Fig. 4). This elongation is apparent at the electron microscopic level. Unfortunately, not enough well fixed material was available to permit statistical analyses. The synaptic pedicles of cones show no differences between the light (Fig. 5) and the dark adapted (Fig. 6) states.

The pure rod retina of the leptocephalus stage (Pankhurst, 1984) is a common adaptive feature rendering an optimal visual function under dim light conditions (Locket, 1975). Light is very dim and practically monochromatic at $500 \mathrm{~m}$. Leptocephali of the American eel and European eel make diel vertical migrations in response to light conditions (Tesch, 1980; Castonguay \& McCleave, 1987).

The presence of a duplex retina in the post-metamorphic eels (glass-eels) is related to the change to a brighter environment. Metamorphosis of the larvae is accompanied by changes in photic conditions (Pankhurst, 1984). The migration of glass-eels into coastal and estuarine environments exposes them to a brighter and spectrally enriched habitat. Glass eels still undergo vertical migrations in coastal and estuarine areas, but they are then part of the selective tidal stream transport mechanism glass-eels use to move landward (Creutzberg, 1958; McCleave \& Kleckner, 1982). Tidal stream transport may occur both in daytime and nighttime. The photomechanical changes of the REP, observed in this study, would permit the masking of outer segments of the rods and isolation of outer segments of the cones in light. This protects the sensitive rod pigments while

Figs 1-2. Photomicrographs of light adapted (Fig. 1) and dark adapted (Fig. 2) retinas. Note the difference in the position of the epithelial pigment (P), $R$ rods, $C$ cones, ENL external nuclear layer, EPL external plexiform layer, INL internal nuclear layer, IPL internal plexiform layer, G ganglion cell. Figs 3-4. Electron micrographs of light (Fig. 3) and dark (Fig. 4) adapted cones. Note the elongation of the myoid (M) in the dark adapted cone (Fig. 3). OS outer segment, E ellipsoid, N nucleus. Figs 5-6. Electron micrographs of cone pedicle of light adapted (Fig. 5) and dark adapted (Fig. 6) retinas. Note that there is no difference between the two states as far as the synaptic ribbons (arrow) are concerned 


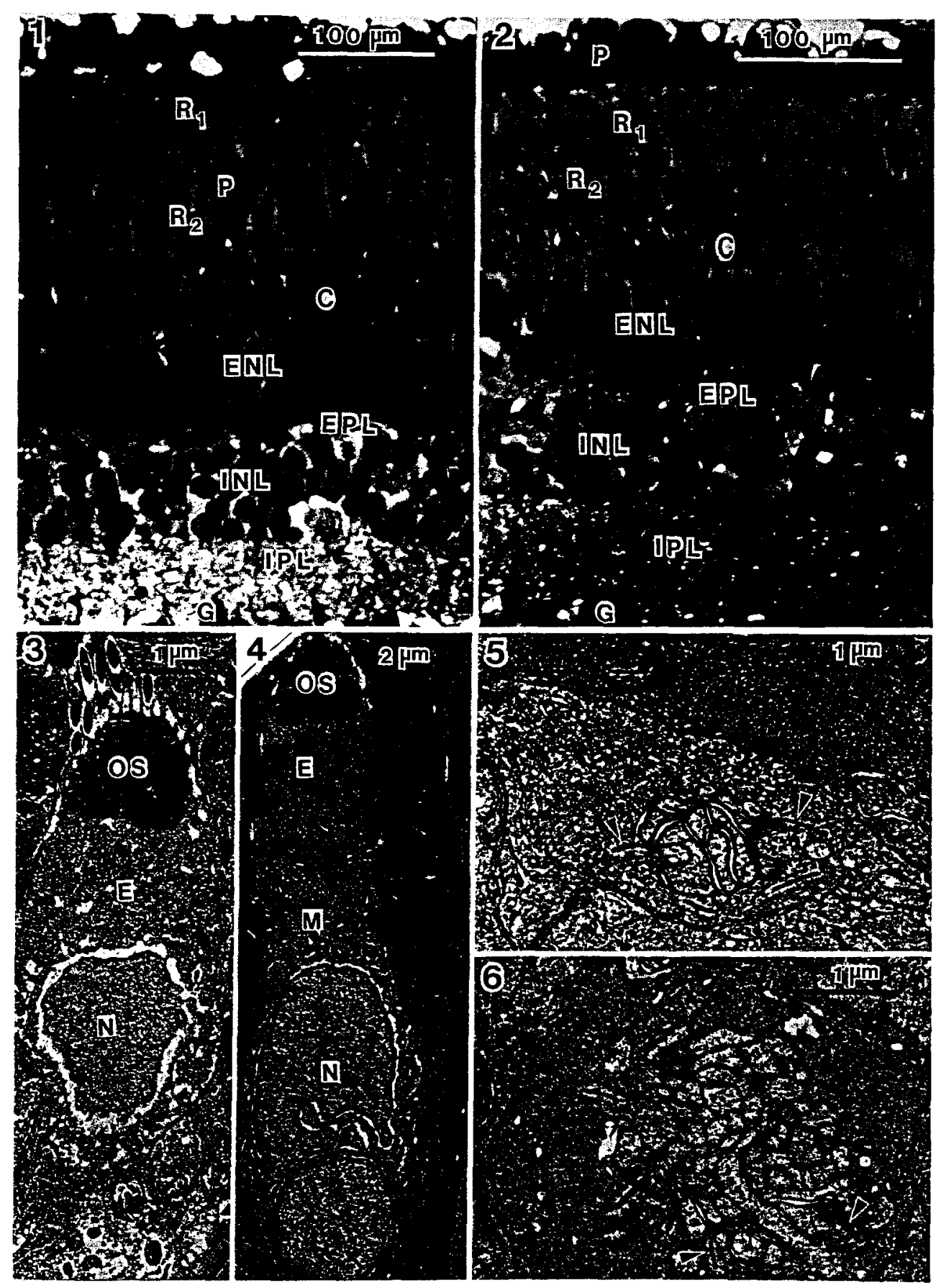


enhancing visual acuity in the light adapted state (Blaxter \& Staines, 1970). Hence post metamorphic eels are able to cope with variations in light intensity both by the possession of rods and cones and the capacity of the screening pigment to migrate into apical processes.

The qualitative observations in this study that there are two types of cones, one stationary (majority) and the other one capable of a slight elongation in darkness and contraction in light, seem to corroborate the electroretinographic results of Gordon et al. (1978) which show two cone-mediated responses in the yellow eel stage of the American eel. One response has a peak sensitivity at $550 \mathrm{~nm}$ and the other at around $450 \mathrm{~nm}$ or less (Gordon et al., 1978).

Since some cones elongate in darkness, the synaptic pedicles of cones from light and dark adapted retinas were examined. However, unlike in other fishes, no differences were observed in synaptic ribbons (Wagner, 1973), spinules (Raynauld et al, 1979; Wagner, 1980) or dense-core and coated vesicles (Monaghan \& Osborne, 1975; Es-sounni \& Ali, 1987). It would be interesting to compare electroretinogram (ERG) spectral sensitivity studies of the post metamorphic stage with the conclusions of our histophysiological study.

\section{LITERATURE CITED}

Ali, M. A., 1971. Les réponses rétinomotrices: caractères et mécanismes - Vision Res. 11, 1225-1288.

Ali, M. A., Anctil, M. \& Mohideen, H. M., 1968. Structure rétinienne et la vascularisation intraoculaire chez quelques poissons marins de la région de Gaspé. - Can. J. Zool. 56, 729-745.

Beatty, D., 1975. Visual pigments of the American eel Anguilla rostrata. - Vision Res, 15, 771-776.

Blaxter, J. H. S. \& Staines, M., 1970. Pure-cone retinae and retinomotor responses in larval teleosts. J. mar. biol. Ass. U. K. 50, 449-460.

Braekevelt, C. 'R., 1982. Retinal fine structure of the European eel Anguilla anguilla. I. Pigment epithelium of the glass eel stage - Anat. Anz. 151, 209-216.

Braekevelt, C. R., 1984a. Retinal fine structure of the European eel Anguilla anguilla. II. Photoreceptors of the glass eel stage - Anat. Anz. 157, 233-243.

Braekevelt, C. R., 1984b. Retinal fine structure of the European eel Anguilla anguilla. III. Pigment epithelium of the yellow eel stage - Anat. Anz. 157, 275-283.

Braekevelt, C. R., 1985. Retinal fine structure of the European eel Anguilla anguilla. IV. Photoreceptors of the yellow eel stage - Anat. Anz. 158, 23-32.

Castonguay, M. \& McCleave, J. D., 1987. Vertical distributions, diel and ontogenetic vertical migrations, and net avoidance of leptocephali of Anguilla spp. and other common species in the Sargasso Sea. - J. Plankt. Res. 9, 195-214.

Creutzberg, F., 1958. Use of tidal streams by migrating elvers (Anguilla vulgaris). - Nature, Lond. $181,857-858$.

Elie, P., Lecomte-Finiger, R., Cantrelle, I. \& Charlon, N., 1982. Définition des limites des différents stades pigmentaires durant la phase civelle d'Anguilla anguilla (poisson téléostéen anguilliforme) - Vie Milieu 32, 149-157.

Es-sounni, A. \& Ali, M. A., 1986. Ultrastructure of the retinal pigmented epithelium of light and dark adapted young pigmented and mature silver eels, Anguilla anguilla (Pisces, Teleostei). Zoomorphology, 106, 179-184.

Es-sounni, A. \& Ali, M. A., 1987. Photoreceptor ultrastructure of light and dark adapted young pigmented and mature silver eels, Anguilla anguilla (Pisces, Teleostei). - Zool. Anz. (In press).

Gordon, I., Shapley, P. M. \& Kaplan, E., 1978. The eel retina. Receptor classes and spectral mechanisms. - J. gen. Physiol. 71, 123-138.

Kleckner, R. C. \& Krueger, W. H., 1981. Changes in swimbladder retinal morphology in Anguilla rostrata during premigration metamorphosis. - J. Fish Biol. 18, 569-577.

Locket, N. A., 1975. Some problems of deep sea fish eyes. In: Vision in fishes: new approaches in research. Ed. by M. A. Ali. Plenum Press, New York, 645-656. 
McCleave, J. D. \& Kleckner, R. C., 1982. Selective tidal stream transport in the estuarine migration of glass eels of the American eel Anguilla rostrata. - J. Cons. int. Explor. Mer. 40, 262-271.

Monaghan, P. \& Osborne, M. P., 1975. Light induced formation of dense-core vesicles in rod photoreceptors in retina of Xenopus laevis. - Nature, Lond. 257, 586-587.

Pankhurst, N. W., 1984. Retinal development in larval and juvenile European eel, Anguilla anguilla (L.). - Can. J. Zool. 62, 335-343.

Pankhurst, N. W. \& Sørensen, P. W., 1984. Degeneration of the alimentary tract in sexually maturing Ánguilla anguilla and American eels Anguilla rostrata. - Can. J. Zool. 62, 1143-1149.

Raynauld, J. P., Laviolette, J. R. \& Wagner, H. J., 1979. Goldfish retina: a correlate between cone activity and morphology of the horizontal cell in cone pedicles. - Science, N. Y., 204, 1436-1438.

Tesch, F. W., 1977. The eel. Chapman \& Hall, London, 434 pp.

Tesch, F. W., 1980. Occurrence of eel Anguilla anguilla larvae west of the European continental shelf 1971-1977. - Environ. Biol. Fish. 5(3), 53-55.

Vilter, V., 1946. Déterminisme intrinsique de migrations pigmentaires dans la rétine. - C.r. Séanc. Soc. Biol. $140,277-278$.

Vilter, V., 1951. Intervention probable de la lumière chez la naissance des structures rétiniennes révélée par l'étude comparée de la rétine chez les anguilles normales et cavernicoles. - C.r. Séanc. Soc. Biol. 145, 54-56.

Wagner, H. J., 1973. Darkness induced reduction of the number of synaptic ribbons in fish retina. Nature, Lond. (Ser: New Biol.) 246, 53-55.

Wagner, H. J., 1980. Light dependent plasticity of the morphology of horizontal cell terminals in cone pedicles of fish retinas. - J. Neurocytol. 9, 573-590. 